\title{
A Ripley Engraved Vessel from East Texas
}

Timothy K. Perttula

Heritage Research Center, Stephen F. Austin State University

Follow this and additional works at: https://scholarworks.sfasu.edu/ita

Part of the American Material Culture Commons, Archaeological Anthropology Commons, Environmental Studies Commons, Other American Studies Commons, Other Arts and Humanities Commons, Other History of Art, Architecture, and Archaeology Commons, and the United States History Commons

Tell us how this article helped you.

This Article is brought to you for free and open access by the Center for Regional Heritage Research at SFA ScholarWorks. It has been accepted for inclusion in Index of Texas Archaeology: Open Access Gray Literature from the Lone Star State by an authorized editor of SFA ScholarWorks. For more information, please contact cdsscholarworks@sfasu.edu. 


\section{A Ripley Engraved Vessel from East Texas}

Creative Commons License

(c) () () (9)

This work is licensed under a Creative Commons Attribution-NonCommercial 4.0 International License 


\title{
A Ripley Engraved Vessel from East Texas
}

\author{
Timothy K. Perttula
}

\section{Introduction}

An ancestral Caddo ceramic vessel from East Texas has been recently donated to the collections of the Texas Archeological Research Laboratory at The University of Texas (TARL). The vessel comes from an unknown site in an unknown East Texas county, and had been purchased in Marshall, Texas some years ago (Marybeth Tomka, September 2017 personal communication). The decorative style of the ceramic vessel, however, does indicate the defined ceramic type, its likely age, and where in East Texas the ceramic vessel was likely manufactured.

\section{Vessel Documentation}

SITE NAME OR SITE NUMBER: Unknown site and unknown East Texas county

VESSEL NO.: Tiemann Vessel No. 1

VESSEL FORM: Carinated bowl

NON-PLASTICS AND PASTE: grog, bone, and hematite

RIM AND LIP FORM: Direct rim and rounded lip

CORE COLOR: $\mathrm{H}$ (fired in a reducing or low oxygen environment and cooled in the open air)

INTERIOR SURFACE COLOR: brown

EXTERIOR SURFACE COLOR: dark grayish-brown

WALL THICKNESS (IN MM): rim, $7.6 \mathrm{~mm}$

INTERIOR SURFACE TREATMENT: smoothed

EXTERIOR SURFACE TREATMENT: burnished

HEIGHT (IN CM): 12.7

ORIFICE DIAMETER (IN CM): 26.0

DIAMETER AT BOTTOM OF RIM OR NECK (IN CM): 25.5

BASE DIAMETER (IN CM) AND SHAPE OF BASE: $8.5 \mathrm{~cm}$, circular and flat

ESTIMATED VOLUME (IN LITERS): 2.0 
DECORATION (INCLUDING MOTIF AND ELEMENTS WHEN APPARENT): The rim panel of the vessel has an engraved scroll and circle motif repeated four times around the vessel (Figure 1). The central element in the motif are four sets of engraved circles with a smaller inner circle. The central circles are connected to each other by engraved slanting scrolls. The upper and lower scroll fill zones have negative ovals outlined by hatched or excised brackets and triangular hatched areas. One negative oval in either upper or lower scroll fill zones has a single short curvilinear excised line or spur within it. The vessel body has vertical brushing marks that extend to within $30 \mathrm{~mm}$ of the vessel base.

PIGMENT USE AND LOCATION ON VESSEL: red pigment in the engraved lines

TYPE AND VARIETY (IF KNOWN): Ripley Engraved, var. Galt (see Fields et al. 2014:Table 8.6; Perttula et al. 2012:Figure 5)

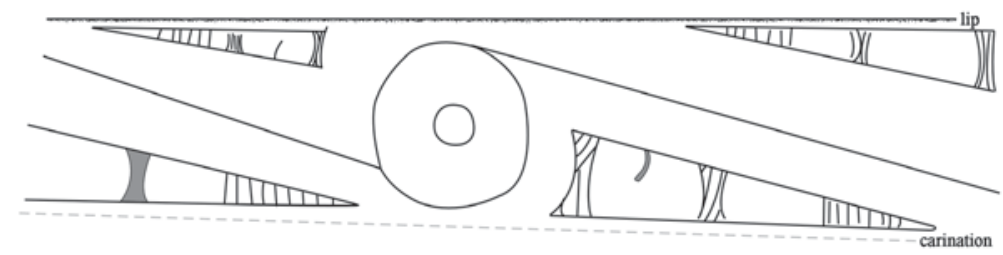

Figure 1. Decorative elements on a Ripley Engraved, var. Galt carinated bowl from East Texas that has been recently donated to TARL.

\section{Summary and Conclusions}

Ripley Engraved, var. Galt carinated bowls were made primarily between ca. A.D. 1430-1600 by Titus phase Caddo peoples (see Perttula 2012). These Caddo peoples lived in widespread settlements and mound centers in both the Big Cypress and Sabine River basins in East Texas (see Fields and Gadus 2012) and these places had family and community cemeteries for adults and children. The burials in these cemeteries were regularly accompanied by a variety of funerary offerings, particularly ceramic vessels of a wide range of forms, sizes, and decorations.

This donated Ripley Engraved, var. Galt carinated bowl almost certainly is from an ancestral Caddo burial feature that was dug in modern times by an East Texas collector, and then sold to an East Texas artifact dealer, where it ended up in the hands of the family member that donated the vessel to TARL. The documentation of this vessel adds specific information on a specific ancestral Caddo ceramic vessel to the Caddo ceramic vessel database of over 7000 vessels from East Texas Caddo sites (see Perttula 2017).

\section{Acknowledgments}

I appreciate the opportunity provided by Marybeth Tomka and Lauren Bussiere of TARL to document this donated ceramic vessel. Lance Trask prepared Figure 1 for this article. 


\section{References Cited}

Fields, R. C. and E. F. Gadus

2012 Archeology of the Nadaco Caddo: The View from the Pine Tree Mound Site (41HS15), Harrison County, Texas. Reports of Investigations No. 164. 2 Vols. Prewitt and Associates, Inc., Austin.

Fields, R. C., V. L. Hatfield, D. Burden, E. F. Gadus, M. C. Wilder, and K. W. Kibler

2014 Testing and Data Recovery Excavations at 11 Native American Archeological Sites along the U.S. Highway 271 Mount Pleasant Relief Route, Titus County, Texas. 2 Vols. Reports of Investigations No. 168. Prewitt and Associates, Inc., Austin.

Perttula, T. K.

2012 The Character of Fifteenth-to Seventeenth-Century Caddo Communities in the Big Cypress Creek Basin of Northeast Texas. In The Archaeology of the Caddo, edited by T. K. Perttula and C. P. Walker, pp. 363-410. University of Nebraska Press, Lincoln.

2017 Caddo Ceramic Vessel Database from Sites in Texas, Louisiana, Oklahoma, and Arkansas. Journal of Northeast Texas Archaeology 71:123-134.

Perttula, T. K., P. S. Marceaux, and B. Nelson

2012 Study of the Margaret Hinton Collection of Pottery Vessels from Northeast Texas Caddo Cemeteries. Archeological \& Environmental Consultants, LLC, Austin and Pittsburg. 